\title{
PENGKAJIAN METODE UNT U K ANALISIS TOTAL LOGAM BERAT DALAM SEDIMEN MENGGUNAKAN MICROWAVE DIGESTION
}

\section{METHOD ASSESSMENT FOR HEAVY METAL ANALYSIS IN SEDIMENT USING MICROWAVE DIGESTION}

\author{
Yayah Rodiana ${ }^{1}$, Hafiz Maulana ${ }^{2}$ Siti Masitoh dan Nurhasni² \\ (Diterima tanggal 02-03-2013; Disetujui tanggal 01-08-2013)
}

\begin{abstract}
ABSTRAK
Destruksi asam tertutup atau disebut juga microwave digestion merupakan metode destruksi basah yang paling direkomendasikan untuk analisis logam berat. Kelebihan dari metode ini diantaranya adalah tidak ada unsur-unsur volatile yang hilang dan waktu pengerjaannya cukup singkat (20-40 menit) dibandingkan dengan destruksi asam terbuka yang membutuhkan waktu lebih lama (lebih dari $24 \mathrm{jam}$ ). Contoh uji yang digunakan dalam penelitian ini adalah sedimen dari Certified Reference Material (CRM). Sebanyak 0,5 gram contoh uji ditimbang kemudian ditambahkan dengan asam $\mathrm{HNO}_{3}$ dan selanjutnya didestruksi menggunakan microwave digestion. Larutan hasil destruksi kemudian diukur konsentrasi logamnya dengan menggunakan Spektrofotometer Serapan Atom (SSA). Validasi metode dilakukan terhadap hasil pengukuran total logam kadmium $(\mathrm{Cd})$, tembaga $(\mathrm{Cu})$, mangan $(\mathrm{Mn})$ dan seng $(\mathrm{Zn})$ meliputi linearitas, limit deteksi, akurasi dan presisi. Hasil penelitian menunjukkan penggunaan metode microwave digestion dengan penambahan $\mathrm{HNO}_{3}$ untuk analisis logam berat telah memenuhi semua persyaratan keberterimaan suatu metode untuk digunakan dalam analisis di laboratorium .
\end{abstract}

Kata kunci: $\mathrm{HNO}_{3}$ logam berat, microwave digestion, sedimen, validasi metode

\section{ABSTRACT}

Closed acid digestion or known as microwave digestion is wet digestion that most recommended to be used as a digestion method in heavy metal analysis. Advantages of this method are no volatile compound will be lost and time for analysis is very short (20-40 minutes) compare to open acid digestion (more than 24 hours). Sediment from Certified Reference Material (CRM) was used as a sample in this research. Weight 0,5 gram of sample, added with $\mathrm{HNO}_{3}$ then continue to digestion process by using microwave. Extract from digestion process was measured by Atomic Spectrophotometer (AAS). Parameters of method validation which used for determine total heavy metals cadmium $(\mathrm{Cd})$, copper $(\mathrm{Cu})$, manganese $(\mathrm{Mn})$, and zinc $(\mathrm{Zn})$ were linearity, detection limit, accuracy and precision. The result showed microwave digestion method with $\mathrm{HNO}_{3}$ addition into sample for heavy metal analysis fulfilled all requirements of acceptability to be used as method in laboratory.

Key words: heavy metal, $\mathrm{HNO}_{3,}$ method validation, microwave digestion, sediment

\section{PENDAHULUAN}

Keberadaan logam berat di perairan merupakan hal alamiah yang terbatas dalam jumlah tertentu di dalam media air, sedimen, dan lemak biota, tetapi keberadaan logam berat ini dapat meningkat akibat masuknya bahan pencemar yang mengandung logam berat dari limbah yang dihasilkan oleh industri-industri serta limbah yang berasal dari aktivitas lainnya. Masuknya bahan pencemar, misalnya logam berat seperti nikel (Ni), kadmium (Cd),

\footnotetext{
${ }^{1}$ Pusarpedal-KLH, Kawasan Puspiptek Gedung 210 Jalan raya Puspiptek-Banten. Email: nengyayah@yahoo.com

${ }^{2}$ Fakultas sains dan teknologi Program studi kimia, universitas Syarif Hidayatullah
} 
timbal $(\mathrm{Pb})$, seng $(\mathrm{Zn})$ dan tembaga $(\mathrm{Cu})$ cenderung meningkatkan kasus keracunan dan gangguan kesehatan masyarakat. Penyebab utama logam berat menjadi bahan pencemar berbahaya karena logam berat tidak dapat dihancurkan (non degradable) oleh organisme hidup di lingkungan dan terakumulasi ke lingkungan, terutama mengendap di dasar perairan membentuk senyawa komplek bersama bahan organik dan anorganik lainnya. Biota air yang hidup dalam perairan tercemar logam berat dapat mengakumulasi logam berat tersebut dalam jaringan tubuhnya. Semakin tinggi kandungan logam berat dalam perairan akan semakin tinggi pula kandungan logam berat yang terakumulasi dalam tubuh hewan tersebut.

Salah satu cara untuk mengukur kadar logam berat di lingkungan adalah dengan menggunakan metode destruksi asam, yaitu melarutkan atau mendestruksi contoh uji menggunakan asam kuat dan dipanaskan, kemudian larutan hasil destruksi tersebut diukur konsentrasi logamnya menggunakan alat Spektrofotometer Serapan Atom (SSA). Pada umumnya, asam yang digunakan dalam preparasi contoh uji sebagai reagen pendestruksi antara lain, $\mathrm{HNO}_{3}, \mathrm{HCl}, \mathrm{H}_{2} \mathrm{SO}_{4}$, $\mathrm{HF}, \mathrm{HClO}_{4}, \mathrm{HNO}_{3}-\mathrm{H}_{2} \mathrm{O}_{2}, \mathrm{HNO}_{3}-\mathrm{HF}, \mathrm{HNO}_{3}-$ $\mathrm{HCl}$. Tujuan dari proses destruksi adalah untuk mendapatkan larutan yang tercampur sempurna dengan analit, dekomposisi yang sempurna dari padatan, da n menghindari hilangnya atau terjadinya kontaminasi analit.

Metode destruksi asam dapat dilakukan secara terbuka maupun tertutup. Metode destruksi asam terbuka yaitu campuran antara contoh uji dengan reagen asam kuat dipanaskan secara terbuka di atas penangas listrik (Hot Plate Method).
Sedangkan destruksi asam tertutup adalah reaksi pelarutan dan pemecahan dilakukan dalam wadah tertutup yang lebih aman terhadap penguapan dan pemuaian bahan. Keuntungan menggunakan metode destruksi asam terbuka adalah peralatan yang digunakan relatif sederhana dan murah, yaitu gelas piala dan penangas listrik. Kelemahan dari metode asam terbuka adalah unsur-unsur yang mudah menguap dari contoh uji dapat hilang selama proses destruksi sehingga memungkinkan terjadinya kesalahan pada hasil analisis, kemungkinan terjadinya kontaminasi dari udara, dan waktu destruksi yang lama mencapai lebih dari 12 jam [1].

Untuk memperbaiki kelemahan dari metode destruksi asam terbuka, maka digunakan metode asam tertutup, salah satu caranya adalah penggunaan gelombang mikro dalam proses destruksi. Metode ini disebut dengan metode microwave digestion. Dalam metode ini contoh uji ditambahkan asam kuat dalam sistem tertutup yang menyebabkan terjadinya peningkatan suhu dan tekanan. Peningkatan suhu dan tekanan serta kondisi dalam $\mathrm{pH}$ rendah pada contoh uji menyebabkan peningkatan kecepatan dekomposisi termal dari contoh uji yang membuat logam menjadi larut. Setelah logam larut, barulah dimungkinkan dilakukan pengukuran dengan instrumen [2].

Metode destruksi dengan menggunakan microwave memiliki beberapa keunggulan, antara lain: kualitas destruksinya tinggi, tidak ada unsur-unsur volatil yang hilang dan waktu yang dibutuhkan untuk proses destruksi relatif singkat yaitu sekitar 20 - 40 menit dibanding metode destruksi konvensional yang membutuhkan waktu lebih dari 24 jam $[3,4]$. 
Beberapa penelitian menunjukkan bahwa nilai persen perolehan kembali (\% recovery) analisis logam berat menggunakan metode microwave digestion memiliki nilai akurasi yang lebih baik dibandingkan dengan destruksi asam terbuka [5].

Pengukuran konsentrasi logam berat yang dilakukan di Pusat Sarana Pengendalian Dampak Lingkungan (Pusarpedal) diantaranya adalah mengukur kadar total logam berat pada contoh uji sedimen sungai menggunakan metode destruksi asam terbuka. Sebagai laboratorium lingkungan rujukan nasional, Pusarpedal mempunyai tugas untuk memutakhirkan metode yang dipakai dalam analisis contoh uji. Berdasarkan hal tersebut di atas, maka Pusarpedal melakukan pengkajian metode analisis logam berat dalam sedimen menggunakan metode microwave digestion dengan tujuan untuk mengetahui apakah metode tersebut dapat digunakan di laboratorium Pusarpedal [6].

Untuk mengetahui apakah suatu metode dapat digunakan sebagai metode standar, maka diperlukan pengkajian terhadap metode tersebut. Pengkajian metoda analisis adalah suatu tindakan penilaian terhadap metode tertentu, berdasarkan percobaan laboratorium, untuk membuktikan bahwa metode tersebut memenuhi persyaratan untuk penggunaannya [7]. Tahapan pengkajian metode yang dilakukan meliputi uji linearitas, limit deteksi, akurasi dan presisi.

Uji linearitas diperlukan karena penentuan kadar logam berat dalam contoh uji secara kuantitatif menggunakan kurva kalibrasi dengan garis lurus (linearitas) yang memenuhi batas keberterimaan. Limit deteksi adalah jumlah terkecil yang dapat dideteksi diatas noise dalam suatu prosedur dan dalam batas kepercayaan tertentu. Akurasi adalah ukuran yang menunjukkan derajat kedekatan hasil analis dengan kadar analit yang sebenarnya dan dinyatakan sebagai persen perolehan kembali (recovery) analit yang ditambahkan. Presisi adalah ukuran yang menunjukkan derajat kesesuaian antara hasil uji individual, diukur melalui penyebaran hasil individual dari rata-rata jika prosedur diterapkan secara berulang pada sampel-sampel yang diambil dari campuran yang homogen. Presisi diukur sebagai simpangan baku atau simpangan baku relatif (koefisien variasi). presisi dapat dinyatakan sebagai repitabilitas (keterulangan) atau reprodusibilitas (ketertiruan) [7].

\section{METODOLOGI}

\section{Waktu dan Tempat Penelitian}

Penelitian ini dilakukan di Laboratorium Tanahdan Padatan Pusat Sarana Pengendalian Dampak Lingkungan (Pusarpedal) Serpong. Penelitian dilaksanakan mulai dari bulan April sampai Agustus 2012.

\begin{abstract}
Alat
Alat-alat yang digunakan dalam penelitian ini diantaranya adalah alat microwave digestion merk CEM tipe Mars 5, Spektrofotometer Serapan Atom (SSA) merk Hitachi tipe Z-2300, kertas saring kualitatif dengan ukuran pori-pori 0,45 $\mu \mathrm{m}$ dari millipore ${ }^{\circledR}$, corong pisah, neraca analitik, dan peralatan gelas lainnya. Untuk menghilangkan kontaminasi logam yang ada pada peralatan maka sebelum melakukan analisis, dilakukan pencucian
\end{abstract}


alat-alat yang akan digunakan dengan $\mathrm{HNO}_{3} 2 \%$, kemudian dibilas dengan aquades, dan dikering anginkan pada suhu ruang.

\section{Bahan}

Bahan-bahan yang digunakan dalam penelitian ini diantaranya adalah : Certified Reference Material (CRM) Montana Soil 2711a10 dari National Institute of Standards and Technology (NIST)-USA, $\mathrm{HNO} 3$ p.a., larutan standar induk $\mathrm{Cd}\left(\mathrm{NO}_{3}\right)_{2}$, $\mathrm{Cu}\left(\mathrm{NO}_{3}\right)_{2}, \quad \mathrm{Mn}\left(\mathrm{NO}_{3}\right)_{2}$, dan $\mathrm{Zn}(\mathrm{NO} 3)_{2}$ dengan konsentrasi $1000 \mathrm{mg} / \mathrm{L}$ dari WAKO, dan air suling.

\section{Penentuan Kadar Air}

Timbang contoh uji CRM 0,5 g kemudian dimasukkan ke dalam oven pada suhu $105^{\circ} \mathrm{C}$ selama 2 jam, kemudian ditimbang kembali. Lakukan secara berulang sampai didapat bobot tetap.

\section{Prosedur Kerja}

\section{Preparasi contoh uji}

Timbang contoh uji CRM 0,5 $\pm 0,0001$ g, tambahkan $10 \pm 0,1 \mathrm{ml} \mathrm{HN03}$ pekat. Tempatkan ke dalam microwave digestion. Contoh uji dipanaskan dengan ramp time 20 menit dan holding time 15 menit. Tabung dibiarkan dingin minimal 5 menit sebelum dikeluarkan dari microwave. Kemudian didinginkan sampai mencapai suhu ruang. Di dalam ruang asam, setiap tabung destruksi dibuka, contoh uji dipindahkan ke botol yang telah di cuci dengan asam. Jika terdapat partikulat, contoh uji harus disaring atau disentrifugasi terlebih dahulu. Larutan destruksi siap diukur dengan menggunakan SSA [2].

\section{Pembuatan dan Pengujian Kurva Kalibrasi} Larutan deret standar logam diukur absorbansinya dengan mengaspirasikan larutan tersebut kedalam spektrofotometer serapan atom. Setelah diukur absorbansinya, maka akan terbentuk kurva, sebagai pembanding, dilakukan pengukuran CRM.

\section{Penentuan Limit Deteksi}

Kurva kalibrasi dibuat dengan menggunakan deret standar sampai titik dimana terjadi penurunan nilai absorbansi. Kemudian dilakukan pengukuran absorbansi larutan ekstraksi dari CRM sebanyak 7 kali pengulangan dengan mengaspirasikannya ke dalam SSA. Setelah didapatkan nilai absorbansinya, dihitung nilai MDL (Method Detection Limit) dengan batas keberterimaan yang dipersyaratkan ( $\% \mathrm{RSD}<0,67$ horwitz)

\section{Penentuan Akurasi dan Presisi}

Dilakukan pengukuran absorbansi larutan hasil ekstraksi CRM sebanyak 7 kali pengulangan dengan menggunakan SSA yang dilakukan dalam 2 waktu yang berbeda untuk mendapatkan nilai konsentrasinya. Dihitung nilai RSD (\%RSD) rerata dan horwitz value rerata (horwitz). Batas keberterimaan akurasi adalah \%recovery $=70-125 \%$. Sedangkan Batas keberterimaan pada repetabilitas adalah $\%$ RSD $<0,67$ horwitz dan reprodusibilitas adalah $\%$ RSD $<$ horwitz.

\section{HASIL DAN PEMBAHASAN}

\section{Kadar Air}

Penentuan kadar air pada penelitian ini adalah untuk mengetahui berat kering CRM, karena nilai berat kering digunakan untuk menentukan nilai konsentrasi CRM pada 
Tabel 1. Data hasil penentuan kadar air

\begin{tabular}{cccccccc}
\hline \multirow{2}{*}{$\begin{array}{c}\text { Pengulangan } \\
\text { CRM }\end{array}$} & \multicolumn{3}{c}{ Berat Basah Awal (gram) } & \multicolumn{2}{c}{ Berat Kering (gram) } & \multirow{2}{*}{ CRM $_{\text {Kering }}$} & \%Kadar Air \\
\cline { 2 - 5 } & Cawan & CRM $_{\text {Basah }}$ & Cawan + CRM Basah $_{n}$ & I & II & & \\
\hline 1 & 17.2703 & 0.5003 & 17.7706 & 17.7635 & 17.762 & 0.4917 & 1.72 \\
2 & 17.1141 & 0.5009 & 17.6150 & 17.6045 & 17.6039 & 0.4898 & 2.22 \\
3 & 17.7889 & 0.5006 & 18.2895 & 18.2800 & 18.2798 & 0.4909 & 1.94 \\
Rerata & & & & & & $\mathbf{0 . 4 9 0 8}$ & $\mathbf{1 . 9 5 8}$ \\
\hline
\end{tabular}

matriks padat yang dikonversi dari nilai konsentrasi hasil pengukuran yang berupa larutan. Data hasil penentuan kadar air CRM dapat dilihat pada Tabel 1.

\section{Konsentrasi Logam Berat dalam Contoh Uji CRM}

Larutan hasil destruksi diukur konsentrasinya masing-masing logam $\mathrm{Zn}, \mathrm{Cu}, \mathrm{Cd}$ dan $\mathrm{Mn}$ menggunakan AAS. Panjang gelombang untuk Zn 213.9 nm, Cu 324.7 nm, Cd 228.8 $\mathrm{nm}$, dan Mn $279.5 \mathrm{~nm}$.
Perhitungan konsentrasi logam berat dalam sampel berdasarkan rumus:

$$
C=\frac{(A-B) d f x m l(A-B) d f x m l}{g}
$$

Keterangan:

$\mathrm{C}=$ Konsentrasi logam dalam sampel $(\mathrm{mg} / \mathrm{kg})$

$\mathrm{A}=$ Konsentrasi logam dalam larutan uji $(\mathrm{mg} / \mathrm{L})$

$\mathrm{B}=$ Rata-rata konsentrasi logam dalam larutan blangko

$\mathrm{df}=$ Faktor pengenceran

gr $=$ Berat sampel yang dianalisis (gram)

Hasil pengukuran logam berat pada contoh uji CRM menggunakan metode microwave digestion dapat dilihat pada Tabel 2.

Tabel 2. Konsentrasi Logam Berat dalam CRM Montana

\begin{tabular}{ccccc}
\hline Pengulangan & $\mathbf{C d} \mathbf{( m g} / \mathbf{k g})$ & $\mathbf{C u}(\mathbf{m g} / \mathbf{k g})$ & $\mathbf{M n} \mathbf{( m g} / \mathbf{k g})$ & $\mathbf{Z n} \mathbf{( m g} / \mathbf{k g})$ \\
\hline 1 & 52.1 & 128.4 & 560.8 & 380.7 \\
2 & 52.6 & 129.2 & 567.1 & 393.1 \\
3 & 52.4 & 129.3 & 567.6 & 398.8 \\
4 & 52.5 & 129.6 & 578.1 & 410.8 \\
5 & 52.4 & 128.8 & 565.1 & 417.2 \\
6 & 52.4 & 131.5 & 562.6 & 424.1 \\
7 & 52.7 & 129.7 & 571.6 & 382.5 \\
Rata-rata & $\mathbf{5 2 . 4}$ & $\mathbf{1 2 9 . 5}$ & $\mathbf{5 6 7 . 6}$ & $\mathbf{4 0 1 . 0}$ \\
Nilai CRM & $\mathbf{5 4 . 1}$ & $\mathbf{1 4 0}$ & $\mathbf{6 7 5}$ & $\mathbf{4 1 4}$ \\
\hline
\end{tabular}




\section{Linearitas Kurva}

Kurva kalibrasi merupakan grafik yang membentuk garis lurus (linear) yang menyatakan hubungan antara kadar larutan kerja termasuk blanko dengan respon yang proporsional dari instrumen [6]. Untuk membuktikan linearitas hubungan antara kadar dengan respon instrumen, maka uji yang paling mudah adalah memvisualisasikan data kalibrasi dalam grafik dan menghubungkan garis linear antar data yang ada. Dengan mengevaluasi secara visual garis yang terbentuk maka dapat dibuktikan linearitas suatu garis tersebut.

Uji linearitas secara visual lebih bersifat subyektif karena berbeda terhadap suatu linearitas. Untuk menghindari hal tersebut, maka digunakan uji linearitas secara statistika dengan menggunakan data kalibrasi yang tersedia. Data uji linearitas dalam penelitian ini dapat dilihat pada Tabel 3 di bawah ini.

Berdasarkan data linearitas di atas, maka kurva kalibrasi untuk semua logam berat berada pada garis lurus (linear). Berikut adalah nilai uji $\mathrm{F}$ untuk logam $\mathrm{Cd}(-7<$ 6,719); $\mathrm{Cu}(0,0047<6,719) ; \mathrm{Mn}(0,0130$ $<6,719)$; dan Zn $(0,0890<6,719)$. Melalui perhitungan dari uji $\mathrm{F}$, dimana nilai $\mathrm{F}_{\text {hitung }}$ yang diperoleh dibandingkan dengan $\mathrm{F}_{\text {tabel }}$, disimpulkan :

a. Jika $\mathrm{F}_{\text {hitung }}<\mathrm{F}_{\text {tabel }}$ : garis yang terbentuk adalah regresi linear

b. Jika $\mathrm{F}_{\text {hitung }}>\mathrm{F}_{\text {tabel }}$ : garis yang terbentuk adalah regresi non-linear

Selain linearitas dengan uji F, keberterimaan validasi linearitas suatu metode juga dilihat dari nilai koefisien korelasi (r) yaitu $\geq 0,995$. Berdasarkan data pada Tabel 2, dapat dilihat semua logam mempunyai nilai $r \geq 0,995$. Sebagai contoh logam Cd, mempunyai nilai $\mathrm{r}$ $=0,9989$ melebihi persyaratan nilai $r \geq 0,995$. Dengan demikian kurva kalibrasi logam $\mathrm{Cd}$ yang dibuat merupakan garis linear.

\section{Limit Deteksi}

Limit deteksi yang dihasilkan dalam validasi ini berupa limit deteksi metode atau Method Detection Limit (MDL) dan Limit of Quantitation (LoQ). Menurut Greenberg (2005), limit deteksi metode adalah konsentrasi terendah yang terbaca dari pengukuran suatu unsur yang mengaplikasikan secara lengkap metode pengukuran suatu unsur tersebut dan hasil pembacaannya dapat dipercaya dengan tingkat kepercayaan $99 \%$ bahwa konsentrasi tersebut berbeda dengan pembacaan blanko [8].

Tabel 3. Linearitas Kurva Kalibrasi

\begin{tabular}{clcccc}
\hline \multicolumn{2}{l}{ Parameter } & $\mathbf{C d}$ & $\mathbf{C u}$ & $\mathbf{M n}$ & $\mathbf{Z n}$ \\
\hline a. & Slope & 0,1222 & 0,0229 & 0,0255 & 0,2236 \\
b. $\quad$ Intercept & 0,0072 & $-0,0009$ & $-0,0020$ & 0,0166 \\
c. & Correlation determination & 0,9977 & 0,9992 & 0,9982 & 0,9987 \\
d. $\quad$ Correlation coeffisien & 0,9989 & 0,9996 & 0,9991 & 0,9993 \\
e. $\quad \mathrm{F}_{\text {hitung }}$ & -7 & 0,0047 & 0,0130 & 0,0890 \\
\multicolumn{2}{l}{ Kesimpulan Linearitas } & Diterima & Diterima & Diterima & Diterima \\
\hline \multicolumn{2}{l}{ Syarat keberterimaan: $\mathrm{r} \geq 0,995$ dan $\mathrm{F}_{\text {hitung }}<\mathrm{F}_{\text {tabel }}$ dimana $\mathrm{F}_{\text {tabel }}=6,719$} & &
\end{tabular}


Penentuan nilai MDL bertujuan mengevaluasi kemampuan metode dalam mengkuantitasi analit. Rumus perhitungan limit deteksi metode adalah :

$\mathrm{MDL}=\mathrm{t}_{\mathrm{n}-1} \times \mathrm{SD}$

Keterangan :

$\mathrm{MDL}=$ Methode Detection Limit

$\mathrm{t}_{\mathrm{n}-\mathrm{1}} \quad=$ nilai $\mathrm{t}$ tabel untuk derajat bebas $\mathrm{n}-1$ dengan tingkat kepercayaan $\quad 99 \%$

$\mathrm{SD}=$ standar deviasi

Selain MDL, didapatkan pula nilai LoQ (Limit of Quantification). LoQ merupakan kadar analit yang menghasilkan signal lebih besar dari blanko pada kondisi kegiatan rutin laboratorium. LoQ ditentukan sesuai persamaan [10]. Nilai LoQ didapat berdasarkan perhitungan:

$\mathrm{LoQ}=3,18 \mathrm{MDL}=3,18(3,143 \mathrm{sd})=10 \mathrm{sd}$

Keterangan :

$$
\begin{array}{ll}
\text { LOQ } & =\text { Limit of Quantification } \\
\text { MDL } & =\text { Methode Detection Limit } \\
\text { SD } & =\text { standar deviasi }
\end{array}
$$

Nilai MDL dan LoQ dari data hasil analisis logam berat dengan contoh uji dapat di lihat pada Tabel 4.

Berdasarkan data dalam Tabel 3, didapatkan nilai MDL untuk parameter $\mathrm{Cd}$ adalah 0,60 $\mathrm{mg} / \mathrm{kg}$ berat kering, lebih rendah daripada MDL Cu (3,06 mg/Kg), Mn (0,68 mg/Kg) dan Zn (5,29 mg/Kg). Data MDL logam Cd 0,60 $\mathrm{mg} / \mathrm{Kg}$ dapat diartikan bahwa kemampuan metode microwave digestion dapat digunakan untuk mengukur konsentrasi total logam dalam contoh uji sedimen $\geq 3,06 \mathrm{mg} / \mathrm{Kg}$.

Sama halnya dengan nilai MDL, metode microwave digestion menghasilkan nilai LoQ paling rendah untuk parameter logam $\mathrm{Cd}$, yaitu $1,90 \mathrm{mg} / \mathrm{Kg}$. Sedangkan nilai LoQ untuk parameter logam lainnya adalah $\mathrm{Cu}: 9,74 \mathrm{mg} /$

\begin{tabular}{|c|c|c|c|c|}
\hline Parameter & Cd & $\mathrm{Cu}$ & Mn & $\mathbf{Z n}$ \\
\hline a. rata-rata konsentrasi (ppm) & 52,4 & 129,5 & 21,7 & 403,6 \\
\hline b. standar deviasi & 0,19 & 0,97 & 0,22 & 1,68 \\
\hline c. $\% \mathrm{R}$ & 96,9 & 92,5 & 100,2 & 97,5 \\
\hline d. $\%$ RSD & 0,36 & 0,75 & 0,99 & 0,42 \\
\hline e. $\operatorname{MDL}(\mathrm{ppm})$ & 0,60 & 3,06 & 0,68 & 5,29 \\
\hline f. $\quad$ LoQ (ppm) & 1,90 & 9,74 & 2,16 & 16,85 \\
\hline Kesimpulan Limit Deteksi & Diterima & Diterima & Diterima & Diterima \\
\hline
\end{tabular}
$\mathrm{Kg}, \mathrm{Mn}: 2,16$ mg/Kg, Zn: 16,85 mg/Kg.

Tabel 4. Data Limit Deteksi Validasi Metode Logam Berat dalam Sedimen 


\section{Akurasi dan Presisi}

Akurasi merupakan perbandingan antara nilai rerata hasil pengulangan dengan nilai benar dari bahan acuan bersetifikat (CRM) yang dinyatakan dalam prosentase. Jika hasil akurasi 100\% maka pengujian yang dilakukan memiliki akurasi yang sangat baik.

Secara matematika akurasi dirumuskan sebagai berikut :

$\%$ akurasi $=\frac{\bar{x}}{\mu} \cdot 100 \%{ }_{\mu}^{\bar{x}} \cdot 100 \%$

\section{Keterangan :}

$\bar{x}=$ rerata hasil pengulangan pengujian $\mu=$ nilai benar atau nilai acuan dalam CRM

Repitabilitas merupakan perbedaan ukuran presisi yang terkecil. Semakin kecil nilai repitabilitas maka semakin kecil presisi hasil pengulangan pengujian yang dilakukan oleh seorang analis. Bila pengulangan pengujian dilakukan lebih dari dua kali maka presisi ditentukan berdasarkan nilai simpangan baku relatif yang dinyatakan dalam prosentase (relative standard deviation), yaitu :\%RSD $=\frac{s d}{\bar{x}} \cdot 100 \% \frac{s d}{\bar{x}} \cdot 100 \%$

Reprodusibilitas adalah hasil keberulangan dari suatu pengukuran yang dilakukan satu laboratorium dengan : 1) sampel dan metode analisis yang sama; 2) analis, peralatan dan waktu yang sama atau berbeda atau hasil keberulangan dari suatu pengukuran yang dilakukan oleh personil dan laboratorium yang berbeda. Perhitungan nilai reprosudibilitas sama dengan persamaan no 5 diatas.diperoleh Data akurasi dan presisi dapat dilihat pada TabeI 5.

Pada proses preparasi, contoh uji diubah dari matriks yang komplek menjadi matriks yang lebih simpel. Akibatnya, nilai konsentrasi hasil pengukuran akan berbeda dengan nilai konsentrasi CRM pada matriks aslinya yang tertera dalam sertifikat [10]. Perbandingan antara nilai konsentrasi hasil pengukuran dengan nilai konsentrasi pada sertifikat dinyatakan dalam \% recovery (\%R), batas keberterimaan \%R adalah 70-125\%. Sedangkan, untuk mengetahui

Tabel 5. Data Akurasi dan Presisi Validasi Logam Berat dalam Sedimen

\begin{tabular}{|c|c|c|c|c|}
\hline Parameter & Cd & $\mathbf{C u}$ & Mn & $\mathbf{Z n}$ \\
\hline \multicolumn{5}{|l|}{ a. Akurasi } \\
\hline$-\% R$ & 96,2 & 92,2 & 100,8 & 97,1 \\
\hline - \%bias & 3,79 & 7,82 & 0,84 & 2,94 \\
\hline \multicolumn{5}{|l|}{ b. Presisi } \\
\hline \multicolumn{5}{|l|}{ b.1 Reprodusibilitas } \\
\hline Pengukuran $1:-\%$ RSD & 0,37 & 0,75 & 1,00 & 0,42 \\
\hline-0.67 horwitz & 5,98 & 5,15 & 6,74 & 4,35 \\
\hline Pengukuran $2:-\%$ RSD & 0,60 & 0,59 & 2,02 & 1,96 \\
\hline-0.67 horwitz & 5,99 & 5,16 & 6,73 & 4,35 \\
\hline b.2 Repitabilitas :-\%RSD & 0,91 & 0,75 & 1,68 & 1,43 \\
\hline -horwitz & 8,83 & 7,70 & 10,06 & 649 \\
\hline Kesimpulan Akurasi dan Presisi & Diterima & Diterima & Diterima & Diterima \\
\hline
\end{tabular}

Syarat keberterimaan: a) Reprodusibilitas : \%RSD $\geq 0.67$ horwitz

b) Repitabilitas : \%RSD $\geq$ horwitz 
konsistensi analis, kestabilan peralatan serta tingkat kesulitan metode pengujian yang digunakan dilihat dari nilai presisi yang dinyatakan dalam \%RSD, dimana persyaratan yang berlaku adalah \% RSD < $20 \%$ [5].

Hasil pengujian akurasi dan presisi pada pengujian ini memenuhi persyaratan pada pengkajian metode. Hal ini dapat berasal dari metode destruksi dan jenis asam yang ditambahkan sebagai reagen pendestruksi contoh uji [11]. Pada umumnya, asam atau campuran asam yang digunakan dalam preparasi contoh uji sebagai reagen pendestruksi antara lain, $\mathrm{HNO}_{3}, \mathrm{HCl}, \mathrm{H}_{2} \mathrm{SO}_{4}$, $\mathrm{HF}, \mathrm{HClO}_{4}, \mathrm{HNO}_{3}-\mathrm{H}_{2} \mathrm{O}_{2}, \mathrm{HNO}_{3}-\mathrm{HF}, \mathrm{HNO}_{3}$ $\mathrm{HCl}$. Dari beberapa asam atau campuran asam tersebut, $\mathrm{HNO}_{3}$ sering digunakan karena dapat melarutkan logam-logam kecuali $\mathrm{Al}, \mathrm{Cr}, \mathrm{Ga}$, Id dan Th yang larut secara lambat dan efisien mengoksidasi senyawa organik pada cuplikan biologis (agen pengoksidasi). Logam-logam dioksidasi kedalam bentuk garamnya, karena nitrat mudah larut di air, sedangkan cuplikan organik didekomposisi menjadi komponen anorganik, dimana bahan organik dioksidasi menjadi $\mathrm{CO}, \mathrm{CO}_{2}, \mathrm{~N}_{2}$, dan lain-lain. Asam nitrat pekat terkena suhu yang tinggi akan mengalami dekomposisi menghasilkan bermacam-macam oksida yang larut dalam air, seperti $\mathrm{NO}, \mathrm{NO}_{2}, \mathrm{NO}^{-}, \mathrm{N}_{2} \mathrm{O}, \mathrm{N}_{2} \mathrm{O}_{3}, \mathrm{~N}_{2} \mathrm{O}_{4}$, $\mathrm{N}_{2} \mathrm{O}_{5}, \mathrm{~N}_{2} \mathrm{O}_{6}, \mathrm{HNO}$ dan $\mathrm{HNO}_{2}$, dengan oksidan tertentu [12].

Berdasarkan data pada Tabel 4 diketahui bahwa nilai akurasi tertinggi terdapat pada unsur Mn yaitu 100,8 \% atau dapat dilihat dari nilai biasnya yang terkecil diantara unsur-unsur yang lain yaitu sebesar 0,84\%. Sedangkan, nilai akurasi terendah terdapat pada unsur $\mathrm{Cu}$ yaitu sebesar $92,18 \%$ dengan nilai biasnya sebesar 7,82 \%. Logam Mn dikategorikan kedalam kation golongan III bersama dengan $\mathrm{Zn}$ dan $\mathrm{Ni}$, golongan ini mudah larut dalam asam encer. Karena dalam penelitian ini digunakan asam pekat, maka penambahan dengan $\mathrm{HNO}_{3}$ pekat pada proses destruksi menunjukkan hasil destruksi untuk kation golongan III Mn dan Zn pada penelitian ini dapat melarutkan logam dengan baik, dilihat dari nilai persen recovery yang lebih besar dibandingkan logam $\mathrm{Cu}$ dan $\mathrm{Cd}$. Dari data yang ada, maka semua unsur yang diukur yaitu $\mathrm{Cd}, \mathrm{Cu}, \mathrm{Mn}$, dan $\mathrm{Zn}$ memenuhi syarat batasan awal \% recovery yaitu $70-125 \%$, dan memiliki nilai presisi yang sangat baik karena memenuhi syarat batasan $\%$ RSD yaitu $<20 \%$.

\section{SIMPULAN}

Hasil pengkajian metode destruksi menggunakan microwave digestion atau destruksi asam tertutup dengan penambahan asam $\mathrm{HNO}_{3}$ untuk logam berat $\mathrm{Cd}, \mathrm{Cu}, \mathrm{Mn}$, dan $\mathrm{Zn}$ memenuhi semua syarat keberterimaan untuk parameter linearitas, limit deteksi, akurasi, dan presisi. berdasarkanBerdasarkan hasil pengkajian metode ini maka metode destruksi menggunakan microwave digestion dapat digunakan untuk mengukur kandungan total logam berat dalam contoh uji sedimen.

\section{UCAPAN TERIMA KASIH}

Ucapan terima kasih penulis sampaikan kepada staf laboratorium tanah dan limbah padat Pusarpedal yang telah membantu ketersediaan contoh uji, bahan standar dan peralatan pengujian sehingga pengkajian terhadap metode ini dapat terlaksana. 


\section{DAFTAR PUSTAKA}

(1) Rochyatun. dan A. Rozak, 2007H. 2003. et Digestion Methods. Comprehensive nalytical

(2) Matusiewicz, H. 2003. Wet Digestion Methods. Comprehensive Analyticalludges, Soils, and Oils., Enviromental Protection Agency. U.S.A.

(3) Berghof. 2005. Theory of Sample Preparation Using Acid Digestion, Pressure Digestion and Microwave Digestion (Microwave Decomposition). Germany.

(4) Inderayani, P. 2008. Perbandingan Destruksi Kering dan Destruksi Basah Pada Penentuan Fe dalam Ubi Kayu (Manihot Esculenta Crantz Sin. M. Utilisslma Pohl) Secara Spektrofotometri Serapan Atom. Tesis. ITS. Surabaya.

(5) Chen, M. and Lena Q.Ma. 1998. Comparison of Four USEPA Digestion Methods for Trace Metal Analysis Using Certified and Florida Soils. Journal of Environmental Quality. Vol. 27 No.6. Univ. of Florida.

(6) Kementrian Lingkungan Hidup. 2009. Pedoman Pengendalian Mutu Internal

Pengujian Parameter Kualitas Lingkungan. Jakarta.
(7) Harmita. 2004. Petunjuk Pelaksanaan Validasi Metode dan Cara Perhitungannya.

Majalah Ilmu Kefarmasian, Vol. I, No.3, hal. 117-135.

(8) Greenberg, A.E. 2005. Standard Methods for the Examination of Water and

Wastewater 21st Edition. American Public Health Association. USA.

(9) Ripp, J. 1996, Analytical Detection Limit Guidance and Laboratory Guide for Determining Method Detection Limit. Wisconsin Departement of Natural Resource Laboratory Certification Program, Madison

(10) Taverniers, I., Loose, M.D., and Bockstaele, E.V. 2004. Trends In Quality In The Analytical Laboratory. II. Analytical Method Validation and Quality Assurance. Trends in Analytical Chemistry, Vol.23, No. 8, 2004. page. 535-552.

(11) AOAC. 2002. Guidelines for Single Laboratory Validation of Chemical Methods for Dietary Supplements and Botanicals, http://www.aoac. org/dietsupp6/Dietary-Supplementweb-site/slv guidelines.pdf (2 Januari 2012 pkl.20:15).

(12) USEPA. 1996, Method 305GB :Acid Digestion of Sediments, Sludges, and Soils., Enviromental Protection Agency. U.S.A. 